\title{
The determination of the nutritive value of a protein by its effect on liver nitrogen in rats
}

\author{
BY KATHLEEN M. HENRY \\ National Institute for Research in Dairying, Shinfield, Reading \\ AND R. M. CORMACK AND H. W. KOSTERLITZ \\ Department of Statistics and Department of Physiology, University of Aberdeen
}

(Received I8 August 1960-Revised I6 December 1960)

Henry, Kosterlitz \& Quenouille (I953) have described a method of determining the nutritive value of a protein by the effect it has on the quantity of protein in the liver of the rat. They found that the liver nitrogen, expressed as $\mathrm{mg} / \mathrm{I} 00 \mathrm{~g}$ body-weight, was correlated with the biological value of the dietary protein and with the amount of protein eaten. When the proteins were tabulated according to the nutritive values obtained by this method, they were, on the whole, arranged in the order of the net utilization values estimated by the balance-sheet method of Mitchell (Mitchell, I923-4; Mitchell \& Carman, I926). Soya-bean protein appeared to be an exception in that the liver- $\mathrm{N}$ method yielded for it rather low nutritive values.

The liver- $\mathrm{N}$ method was based on the fact that, for relatively small protein intakes, the values of liver $N(\mathrm{mg}) / 100 \mathrm{~g}$ initial body-weight varied linearly with the amount of a protein eaten, provided the nutritive value of the protein was not better than that of casein. Whole-egg protein, for instance, gave a non-linear regression line. It therefore appeared desirable to attempt to determine the shape of the dose-response curve over a wide range of protein intakes. Unfortunately, we have to report that experiments designed to achieve this aim had only limited success and that it was not possible to improve on the seven- and eight-point assays described in the earlier paper; these assays were used to assemble more information on nutritive values of various proteins and to assess the effects of supplementation of proteins by their limiting amino acids.

Though inherent difficulties of the method might have been responsible for some of the discrepancies observed between the results obtained by the liver- $\mathrm{N}$ and the balance-sheet methods, other possibilities had to be explored. Since hormonal imbalances may affect liver protein and $\mathrm{N}$ balance in opposite directions, the results of a few preliminary experiments on the effects of cortisone on the nutritive values of proteins are included in this paper.

\section{EXPER I MENT AL}

\section{Liver- $N$ method}

Animals. Hooded Norwegian litter-mate male rats bred at Shinfield were used. They weighed about $100 \mathrm{~g}(80-\mathrm{I} 20 \mathrm{~g})$ at the beginning of the experiments and were between $4 \frac{1}{2}$ and $5 \frac{1}{2}$ weeks old. 
Diets. The basal N-free diet had the percentage composition: sugar I2, potato starch 10, margarine fat 10, salts (de Loureiro, 1931) 4 and rice starch 64. In the experiments with flour the amounts of margarine fat and potato starch were both reduced to $7 \%$ and the amount of rice starch was increased to $70 \%$. The protein source to be tested was added at the expense of an equal weight of rice starch (rice starch and sugar in the experiments with flour). In the earlier experiments (nos. I-23) each rat received daily, on a separate dish, $0.5 \mathrm{ml}$ of the mixture of water-soluble vitamins described by Campbell \& Kosterlitz (1948) together with cod-liver oil as a source of vitamins $A$ and $D$. In the later experiments (nos. 24-42) water-soluble vitamins were thus added to each $\mathrm{kg}$ of diet: biotin $0.6 \mathrm{mg}$, folic acid $0.6 \mathrm{mg}$, menaphthone (2-methyl- $1: 4$-naphthaquinone) $2 \cdot 2 \mathrm{mg}$, thiamine $3.3 \mathrm{mg}$, pyridoxine $3.3 \mathrm{mg}$, riboflavin $5.5 \mathrm{mg}$, calcium pantothenate I I $\mathrm{mg}, p$-aminobenzoic acid I I $\mathrm{mg}$, nicotinic acid I mg, inositol I I $\mathrm{mg}$, choline hydrochloride $1900 \mathrm{mg}$, cyanocobalamin $20 \mu \mathrm{g}$. At the beginning of each experiment each rat was given a single dose of $\mathrm{I}_{4} \cdot 4 \mathrm{mg}$ $\alpha$-tocopheryl acetate, 360 i.u. vitamin $A$ and 26 i.u. vitamin $D$ in arachis oil.

Feeding. The diets containing the test proteins were given for 10 days and the protein-free diet for 5 days. The rats were offered daily $9 \mathrm{~g}$ food/100 $\mathrm{g}$ body-weight; they usually consumed between 8 and $9 \mathrm{~g}$. The diets were mixed to a thick paste with water to prevent scattering. The total amount of food eaten during the experimental period was recorded.

Liver analysis. The method was that described previously (Henry et al. 1953). The results were expressed as mg liver N/100 g initial body-weight.

Seven- and eight-point assays. The general design was that given in the previous paper (Henry et al. 1953). Three or four proteins were examined in any one test. With three proteins, seven litters of seven rats were used, six rats from each litter being fed on diets containing the test protein in two concentrations, $a$ and $2 a$, and one rat on a protein-free diet. With four proteins, eight litters of eight rats were used; diets with concentrations $a$ and $2 a$ of each protein were given to all the rats of a litter, none being on a protein-free diet. Randomization and choice of protein concentration were carried out as previously; the level of protein intake $a$ was varied between 3 and $8 \mathrm{~g} / \mathrm{I} 00 \mathrm{~g}$ diet. This variation had no significant effect on the nutritive value but the number of experiments was too small to exclude such an effect with certainty.

Regression equations having a common zero point were calculated. When the response curves were linear, the ratios of the slopes were taken to be a measure of the ratios of the nutritive values. However, since the response curves, particularly those for whole egg or methionine-supplemented soya-bean meal or casein, were sometimes non-linear, the convention was accepted of comparing the various proteins at $\mathrm{N}$ intakes of $100 \mathrm{mg} / \mathrm{I} 00 \mathrm{~g}$ initial body-weight. For the calculation of the nutritive value of a given protein, the value for the liver $\mathrm{N}$ at zero $\mathrm{N}$ intake was deducted from that for the liver $\mathrm{N}$ at an intake of $100 \mathrm{mg} / \mathrm{I} 00 \mathrm{~g}$ initial body-weight. The nutritive value of whole-egg protein was usually taken to be Ioo (cf. Table I). Sometimes, however, it was assumed that the nutritive value of whole-egg protein was equal to the mean net utilization of $92 \cdot 3$ obtained by the balance-sheet method (see Fig. 2), or else casein, with a mean net utilization value of $8 \mathrm{r} \cdot 9$ (see Fig. 3 ), was used as reference protein. 
In assays with four proteins the value of liver $\mathrm{N}$ for zero intake was estimated from the point of concurrence of the regression equations as no rats were fed on a proteinfree diet. The mean liver- $\mathrm{N}$ value for zero intake found in fifteen such assays was $9 \mathrm{I} \cdot 2 \mathrm{mg} / \mathrm{IOO} \mathrm{g}$ initial body-weight, ranging from $79 \cdot 8$ to 104.6 . In fourteen sevenpoint assays, where one group of rats was fed on a protein-free diet, the mean liver- $\mathrm{N}$ value for zero $\mathrm{N}$ intake was $92.3 \mathrm{mg} / \mathrm{I} 00 \mathrm{~g}$ initial body-weight, ranging from 85.8 to 98.5. The scatter was significantly smaller in the latter group than in the former.

Shape of the dose-response curve. To determine the dose-response curve for casein in relation to that for egg proteins, rats were given diets containing casein or dry defatted whole egg in concentrations of $0,3,6,12,24$ and $48 \mathrm{~g}$ protein/100 $\mathrm{g}$ diet. Twelve litters, each of six rats, were used in an incomplete block design. It was of a cyclic type, being the same for each group of six concentrations. Experiments to compare soya with egg proteins were unsuccessful.

Effect of cortisone. Eight litters, each of eight rats, were divided into ten groups. They were given five diets with or without cortisone: protein-free, 8 and $\mathrm{I} 6 \mathrm{~g}$ casein/ roo $\mathrm{g}$ diet and 8 and $\mathrm{I} 6 \mathrm{~g}$ wheat gluten/roo g diet. All rats were given a daily subcutaneous injection ( $(0.1 \mathrm{ml})$ of normal saline containing $0.5 \%$ sodium carboxymethylcellulose, $0.4 \%$ polysorbate 80 U.S.P. ('Tween 80 , polyoxyethylene sorbitan monooleate) and $0.9 \%$ benzyl alcohol; the cortisone groups were given $2.5 \mathrm{mg}$ cortisone acetate as a suspension in this solution (Cortellan, Glaxo Laboratories Ltd). An incomplete block design was adopted in which groups of four rats were given the diets containing $8 \%$ protein and groups of eight rats were given the protein-free and I6\% protein diets.

\section{Balance-sheet method}

The biological values, true digestibilities and net utilization values (biological value $\times$ true digestibility $\div$ Ioo) of proteins were determined by the balance-sheet method (Mitchell, I923-4; Mitchell \& Carman, I926) as modified by Henry, Kon \& Watson (1937), Henry, Kon, Lea \& White (1947-8) and Henry \& Kon (1956). The same basal diet, with the same vitamin supplements, was used as in the liver-N experiments; the protein concentration was always $8 \mathrm{~g} / \mathrm{loO} \mathrm{g}$ diet. In the experiments to test the effect of cortisone four litters of four rats were used, one pair in each litter being given $2.5 \mathrm{mg}$ cortisone daily as in the liver- $\mathrm{N}$ tests. Each pair of rats was given one of the diets in turn as usual but there was no change-over between the cortisone and control groups.

\section{Sources of proteins tested}

In computing the protein content of the diets the conventional factors used were $\mathrm{N} \times 6 \cdot 3^{8}$ for egg and casein and $\mathrm{N} \times 6 \cdot 25$ for other proteins.

Egg. Four samples of laboratory-prepared ether-extracted whole egg were used; the $\mathrm{N}$ content varied between 10.5 and I $.6 \%$.

Casein. Four samples of extracted casein were used. Sample I (Expts I, 3, 4 and 5) was vitamin-free casein (Glaxo Laboratories Ltd) with a $\mathrm{N}$ content of $14.3 \%$. The other three samples were vitamin-low casein (Genatosan Ltd) and contained between I 3.3 and $14 . \mathrm{I} \% \mathrm{~N}$. 
Soya-bean meal. Five samples of heat-treated soya-bean meal were used; samples I4 were obtained direct from the Glidden Co., Chicago, Illinois, and sample 5 from Soya Foods Ltd, Cardiff. Their N contents varied between $6 \cdot 7$ and $8.4 \%$.

Isolated soya proteins (Drackett). This product was obtained from the Drackett Co., Cincinatti, Ohio, and contained $12.3 \% \mathrm{~N}$.

Flours. The flours of 70 and $100 \%$ extraction rates were purchased in Reading and contained $\mathrm{I} \cdot 84$ and $2.07 \% \mathrm{~N}$, respectively.

Wheat gluten. It was purchased from Procea Products Ltd, London, and contained II $5 \%$ N.

Dried peas. They were bought locally (Shinfield); their N content was $3 \cdot 36 \%$.

Linseed meal. The two samples used in Expts 24 and 32 were obtained from the farm of the National Institute for Research in Dairying; they contained 4.77 and $4.94 \%$ N, respectively.

Yeast. Two samples of dried brewer's yeast were obtained from Arthur Guinness, Son \& Co. (Dublin) Ltd, Park Royal, London, and contained (Expt 4) $6.06 \%$ and (Expt 32) $6 \cdot 79 \% \mathrm{~N}$.

\section{RESULTS}

Shape of the dose-response curve

The results for egg and casein (Fig. I) could be fitted equally well to curves of the type $y=c+a x^{b}$ or $y=d+e x+f x^{2}$. The equations were

and

$$
\begin{aligned}
& y(\text { egg })=88+\mathrm{I} \cdot 76 x^{0 \cdot 65} \\
& y(\text { casein })=88+\mathrm{I} \cdot 42 x^{0 \cdot 65}
\end{aligned}
$$

$$
\begin{aligned}
& y(\text { egg })=93.8+0.266 x-0.00015 x^{2}, \\
& y(\text { casein })=93.8+0.221 x-0.00013 x^{2},
\end{aligned}
$$

where $y$ is the liver $\mathrm{N}(\mathrm{mg} / \mathrm{loo} \mathrm{g}$ initial body-weight) and $x$ is the mean daily protein intake ( $\mathrm{mg} \mathrm{N} / \mathrm{roo} \mathrm{g}$ initial body-weight). Since in the first pair of equations the constant $b$ is identical and in the second the coefficients of linear and quadratic terms are in almost equal ratios, the ratios of $a$ and of $e$ and $f$ may be expected to give the ratios of the nutritive values of egg and casein. Thus,

and

$$
a(\text { casein }) / a(\mathrm{egg})=0.8 \mathrm{r},
$$

$$
\begin{aligned}
& e(\text { casein }) / e \text { (egg) }=0.83, \\
& f(\text { casein }) / f(\text { egg })=0.8 \mathrm{I} .
\end{aligned}
$$

The values are independent of protein intake and agree well with the mean net utilization value for casein of $8 \mathrm{I} \cdot 9$ (Table 2) obtained by the balance-sheet method. They are higher than the mean value of 6r (Table r), obtained in a large number of seven- or eight-point assays.

There was no theoretical justification for preferring one form of curve to another, nor did the experimental results help in reaching such a decision. Until information on the shape of the curve can be obtained, it seems impossible to improve on the precision of the seven- or eight-point assays reported in the earlier paper (Henry et al. 1953). 


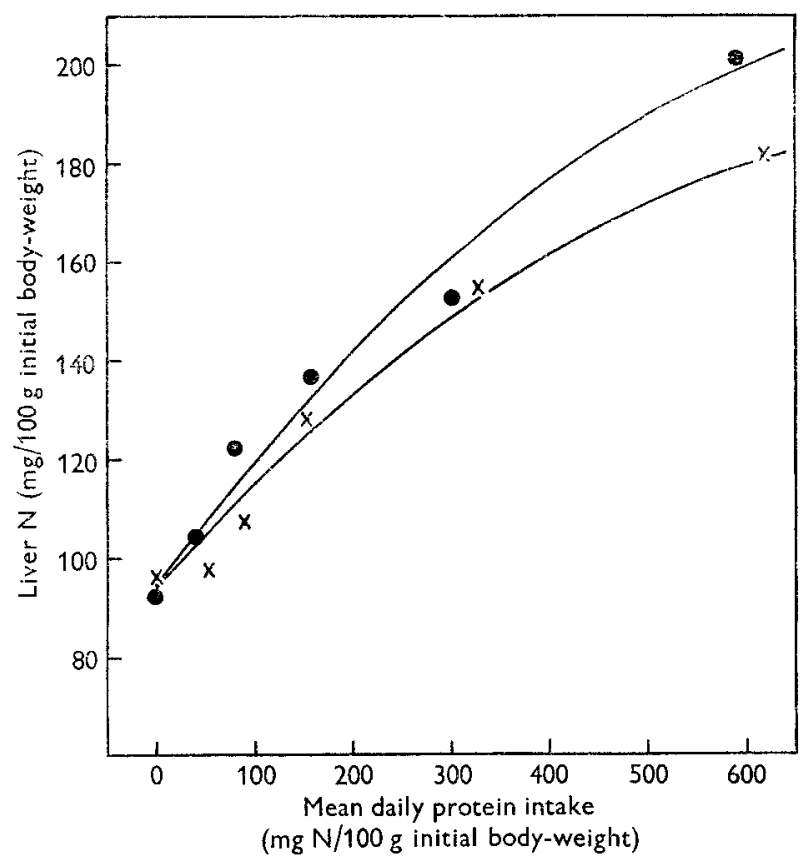

Fig. I. Dose-response curves obtained by the liver-nitrogen method with rats for diets containing egg or casein. 0 , egg; $x$, casein. The lines were drawn from the regression equations: $y$ (egg) $=93.8+0.266 x-0.00015 x^{2}$ and $y$ (casein) $=93.8+0.221 x-0.00013 x^{2}$, where $y$ is liver $\mathrm{N}$ and $x$ mean daily protein $\mathrm{N}$ intake.

Table I. Nutritive values for rats of proteins, determined by the liver-nitrogen method

(Values given in the earlier paper of Henry et al. (1953) are included)

Mean liver $\mathrm{N}$ (mg/roo g initial body-weight)

\begin{tabular}{|c|c|c|c|c|c|}
\hline & & Mean liver $N(n$ & $\mathrm{g} / \mathrm{roO} \mathrm{g}$ init & dy-weight) & \\
\hline Protein source & $\begin{array}{l}\text { No of } \\
\text { seven- } \\
\text { or eight-point } \\
\text { assays }\end{array}$ & $\begin{array}{l}\text { At a protein } \\
\text { intake of } \\
\text { roo mg N/roo g } \\
\text { initial } \\
\text { body-weight } \\
(a)\end{array}$ & $\begin{array}{l}\text { At zero } N \\
\text { intake } \\
(b)\end{array}$ & $\begin{array}{c}\text { Increase } \\
(a-b)\end{array}$ & $\begin{array}{c}\text { Nutritive } \\
\text { value } \\
\text { (egg }=\text { roo) }\end{array}$ \\
\hline & IO & $135 \cdot 1$ & $90 \cdot 5$ & $44 \cdot 6$ & 100 \\
\hline & I9 & I I9:I & $92 \cdot I$ & 27.0 & $6 I$ \\
\hline & 2 & $116 \cdot 7$ & $90 \cdot 7$ & $26 \cdot 0$ & $5^{8}$ \\
\hline ed soya (Drackett) & 2 & I $15 \cdot 6$ & $9 I \cdot 2$ & $24 \cdot 4$ & 55 \\
\hline 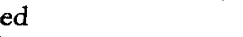 & 2 & $117 \cdot 3$ & $93^{\circ} 9$ & $23 \cdot 4$ & 52 \\
\hline extraction flour & 3 & $108 \cdot 2$ & $89 \cdot 4$ & $18 \cdot 8$ & 42 \\
\hline & II & $\operatorname{II2\cdot 4}$ & $94 \cdot 3$ & $18 \cdot 1$ & $4 I$ \\
\hline eas & $I$ & I 10.6 & $92 \cdot 5$ & I $8 \cdot \mathrm{I}$ & $4^{I}$ \\
\hline traction flour & 3 & $106 \cdot 0$ & $89 \cdot 4$ & 16.6 & 37 \\
\hline gluten & 3 & $104: 7$ & 89.0 & $15 \cdot 7$ & 35 \\
\hline
\end{tabular}


The nutritive values of proteins obtained by seven- or eight-point assays

This type of assay makes use of the initial part of the dose-response curve that, for most proteins, does not deviate significantly from linearity. When the dose-response

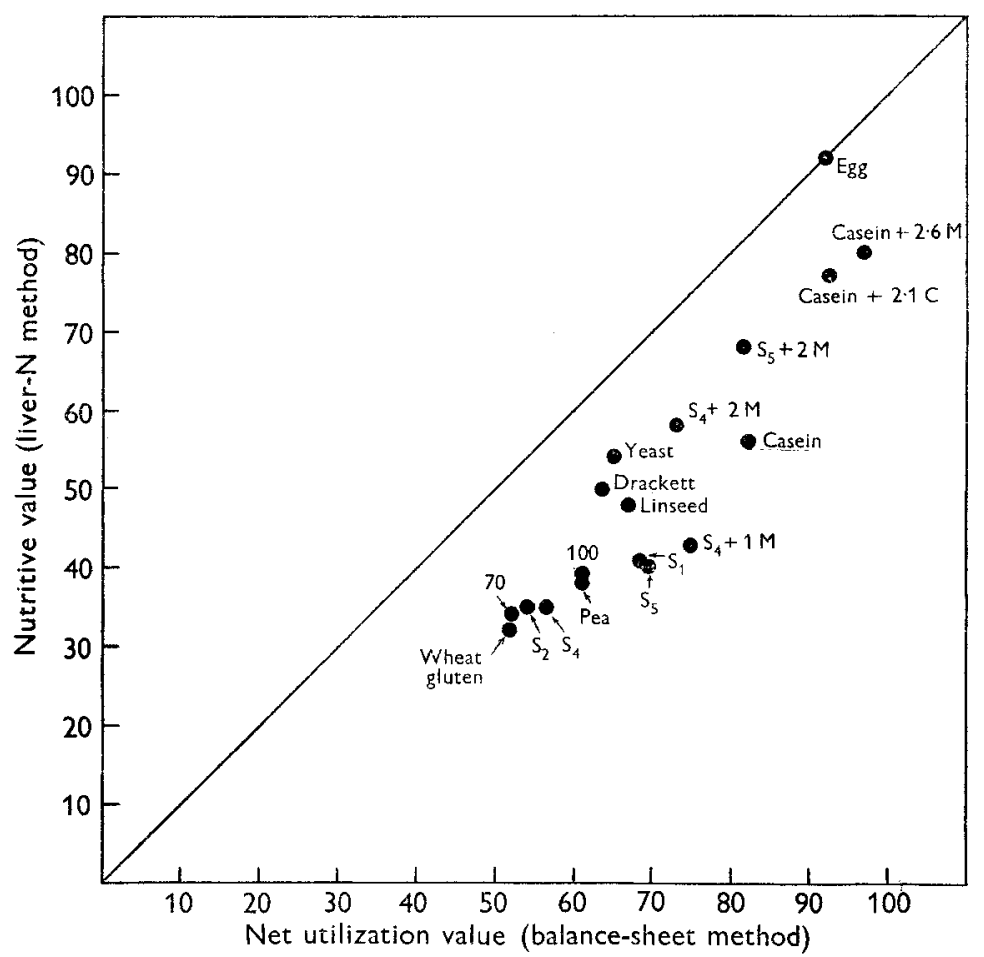

Fig. 2. Nutritive values of proteins obtained with rats by the liver-nitrogen method with the seven- or eight-point assay plotted against net utilization values obtained by the balance-sheet method. The reference protein was whole egg with a nutritive value taken to be $92 \cdot 3$. Sources of values: Tables $\mathrm{I}-8$ of this paper and 'Table 4 of Henry et al. (I953). $\mathrm{S}_{1}, \mathrm{~S}_{2}, \mathrm{~S}_{4}, \mathrm{~S}_{5}$, soya protein samples $\mathrm{I}, 2,4,5 ; \mathrm{I}, 2 \mathrm{M}, 2.6 \mathrm{M}$, supplements of $\mathrm{I}, 2,2.6 \mathrm{~g}$ DL-methionine $/ \mathrm{I} 6 \mathrm{~g}$ protein $\mathrm{N} ; 2 \cdot \mathrm{IC}$, supplement of $2 \cdot \mathrm{I} \mathrm{g}$ L-cystine $/ 16 \mathrm{~g}$ protein $\mathrm{N} ; 70,100,70 \%$ and $100 \%$ extraction flours. Drackett, isolated soya proteins (see p. 202).

Table 2. Nutritive value for rats of proteins, determined by the balance-sheet method at a protein concentration of $8 \mathrm{~g} / \mathrm{r} 00 \mathrm{~g}$ diet

(Ranges of values in parentheses; each observation is the mean of twelve values obtained on individual rats)

No. of observa-

Protein source

\section{Egg}

Casein

Linseed

Yeast

Soya

Isolated soya (Drackett)

Dried peas

Wheat gluten

tions Biological value

$\begin{array}{rl}3 & 94 \cdot 6(93 \cdot 0-97 \cdot 3) \\ 10 & 82 \cdot 9(79 \cdot 2-87 \cdot 6) \\ 2 & 78 \cdot 4(76 \cdot 4 ; 80 \cdot 4) \\ 2 & 74 \cdot 7(71 \cdot 8 ; 77 \cdot 3) \\ 10 & 71 \cdot 3(55 \cdot 3-79 \cdot 7) \\ \text { I } & 65 \cdot 2 \\ \text { I } & 66 \cdot 1 \\ 2 & 53.5(50 \cdot 5 ; 56 \cdot 4)\end{array}$

True digestibility

$97 \cdot 5(97 \cdot 0-97 \cdot 8)$

$98 \cdot 8(98 \cdot 6-99 \cdot 3)$

$85 \cdot 1(83 \cdot 6 ; 86 \cdot 6)$

$86 \cdot 4(84 \cdot 1 ; 88 \cdot 7)$

$89^{\circ} 4(84 \cdot 8-92 \cdot 0)$

$97 \cdot 3$

$92 \cdot 2$

$95 \cdot 9(95 \cdot 8 ; 95 \cdot 9)$
Net utilization value

$92 \cdot 3(90 \cdot 2-95 \cdot 0)$
$81 \cdot 9(77 \cdot 9-86 \cdot 5)$
$66 \cdot 8(63 \cdot 9 ; 69 \cdot 6)$
$64 \cdot 6(60 \cdot 5 ; 68 \cdot 6)$
$63 \cdot 8(47 \cdot 0-71 \cdot 8)$
$63 \cdot 5$
$60 \cdot 9$
$51 \cdot 8(48 \cdot 4 ; 54 \cdot 1)$

$8 \Gamma^{\circ} \cdot 9(77 \cdot 9-86 \cdot 5)$

(6).8 $(63 \cdot 9 ; 60 \cdot 6)$

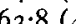

$5 I \cdot 8\left(48 \cdot 4 ; 54^{\cdot I}\right)$ 
curve was non-linear the nutritive values were compared at $\mathrm{N}$ intakes of $100 \mathrm{mg} / \mathrm{100} \mathrm{g}$ initial body-weight.

The nutritive values obtained by the liver- $\mathrm{N}$ method are given in Table $\mathrm{I}$ and the net utilization values determined by the balance-sheet method in Table 2. In order to facilitate comparison of the two sets of values, they were plotted against each other in Figs. 2 and 3. In Fig. 2 the reference protein was whole egg, and its nutritive value was taken to equal its net utilization value of $92 \cdot 3$. The nutritive values by the liver- $\mathrm{N}$ method were low in comparison with those obtained by the balance-sheet method for

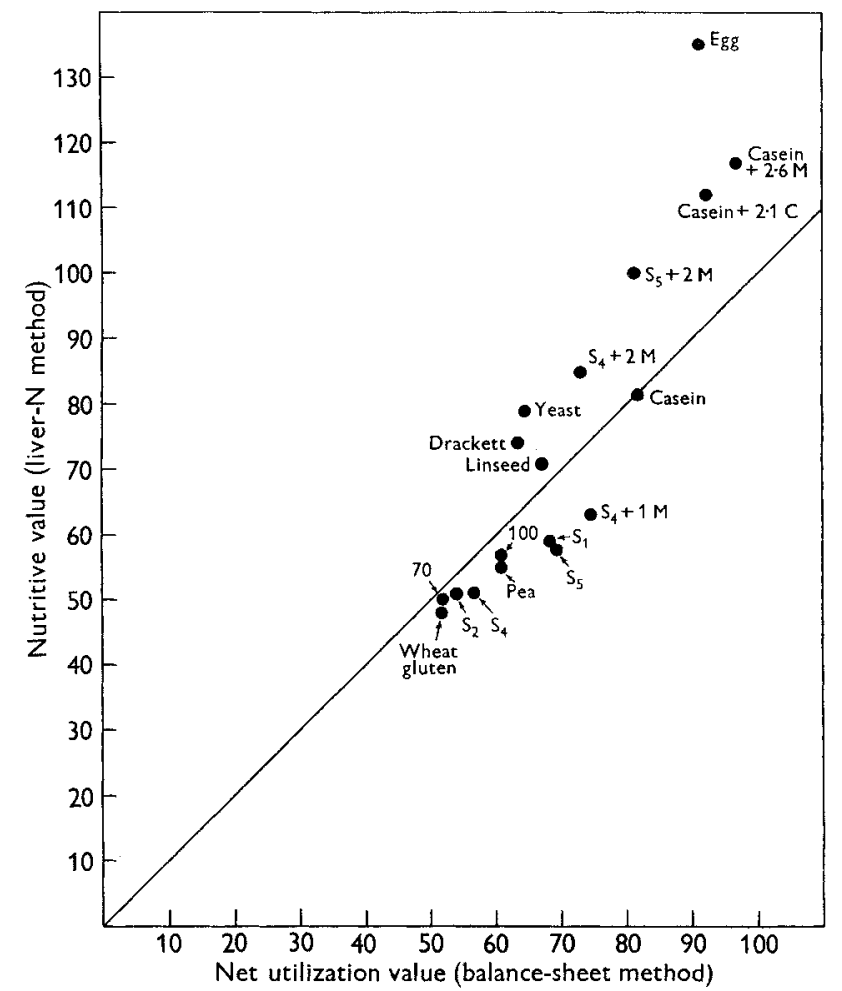

Fig. 3. Nutritive values of proteins obtained with rats by the liver-nitrogen method with the seven- or eight-point assay plotted against net utilization values obtained by the balancesheet method. The reference protein was casein with a nutritive value taken to be $81 \cdot 9$. Sources of values and abbreviations are as in Fig. 2.

all proteins other than egg, although there was fairly good agreement between the two methods as far as the relative values of the proteins were concerned. In Fig. 3 casein was the reference protein; its nutritive value was taken to be equal to its net utilization value, $8 \mathrm{r} \cdot 9$. The nutritive values determined by the liver- $\mathrm{N}$ method were now much closer to the values obtained by the balance-sheet method, some too high and some too low. The deviation was most marked for proteins with nutritive values better than casein.

Nutritive values derived from individual liver- $\mathrm{N}$ assays showed a considerably larger scatter than the net utilization values similarly obtained by the balance-sheet 
method (see Tables $2,3,7,8$ ). In view of this large variation, no statistical comparison was made between nutritive values obtained from different liver- $\mathrm{N}$ assays. When two proteins were to be compared, or when the effect of supplementation by limiting amino acids was examined, the assay was so designed that there was a direct comparison within the assay.

\section{Direct comparison of the nutritive values of some proteins}

Flours of 70 and $100 \%$ extraction. With the liver-N method, Henry et al. (1953) found that for young growing rats the proteins of $100 \%$ extraction flour were superior in nutritive value to those of $70 \%$ extraction flour. Though the finding was statistically significant $(P=0.03)$, this experiment was repeated in two further assays

Table 3. Direct comparison of the nutritive values for rats of some proteins, determined by the liver-nitrogen method

Increase $(\mathrm{mg} / \mathrm{ro0} \mathrm{g}$ initial body-weight) in liver- $\mathrm{N}$ for a rise in protein intake from $\circ$ to roo $\mathrm{mg} \mathrm{N} / \mathrm{roO} \mathrm{g}$ initial body-weight

\begin{tabular}{|c|c|c|c|c|c|}
\hline Protein source & Expt 3 & Expt 4 & Expt 5 & Expt 24 & Expt 32 \\
\hline Casein & $2 I \cdot 4$ & $24 \cdot 5$ & $29 \cdot 2$ & $25^{\circ} \mathrm{O}$ & $29 \cdot 2$ \\
\hline Yeast & - & $26 \cdot 3$ & - & - & $25 \cdot 7$ \\
\hline Linseed & 一 & - & 一 & $23 \cdot 7$ & $23 \cdot 3$ \\
\hline roo $\%$ extraction flour & $19 \cdot 2$ & - & 19.5 & - & - \\
\hline $70 \%$ extraction flour & $17 \cdot 3$ & - & $19 \cdot 1$ & 一 & 一 \\
\hline Wheat gluten & I5:I & - & $18 \cdot 3$ & $\ldots$ & - \\
\hline
\end{tabular}

Concentrations of proteins (g/roo g diet): Expts 3 and 5 -casein and wheat gluten 8 and 16 ; flours $4^{*} 5$ and 9

Expt $4-8$ and 16

Expts 24 and $32-6$ and 12

Significance of differences:

Expt 3 -wheat gluten $<$ casein $(P<0.05)$

Expt 5 - wheat gluten and both flours $<$ casein $(P<0.01)$

Expt 32 -linseed $<$ casein $(P<0.01)$

(Table 3) when no difference was found between the proteins of the two flours. Further, there was no significant difference between the flour proteins and wheat gluten. However, when the results of all three assays were combined, the nutritive values and net utilization values of $100 \%$ extraction flour appeared to be better than those of $70 \%$ extraction flour, although no statistical significance could be attached to the differences between the flours (Figs. 2 and 3). Wheat gluten was inferior to casein and so were the flour proteins in one of two assays (Table 3 ).

Linseed and yeast proteins. The proteins of linseed meal were found to be inferior to casein in one liver- $\mathrm{N}$ assay and about equal in another. This method failed to show any difference between casein and the proteins of brewer's yeast (Table 3 ). However, proteins of both yeast and linseed were inferior to casein with the balance-sheet method (Table 2). 


\section{Supplementation of proteins}

Soya proteins. It is well known that the low biological value of these proteins is due to their low methionine content. Some of the samples of soya proteins used had lower nutritive and net utilization values than others (Figs. 2 and 3). Supplementation with methionine improved the soya proteins whether the assay was made by the

'Table 4. Effect of methionine supplements on the nutritive value for rats of soya proteins, determined by the liver-nitrogen method

\begin{tabular}{|c|c|c|c|c|}
\hline \multirow{2}{*}{$\begin{array}{c}\text { DL-methionine } \\
\text { supplement } \\
(\mathrm{g} / \mathrm{1} 6 \mathrm{~g} \text { protein } \mathrm{N})\end{array}$} & \multicolumn{4}{|c|}{$\begin{array}{l}\text { Increase }(\mathrm{mg} / \mathrm{r} 00 \mathrm{~g} \text { initial body-weight) in liver } \mathrm{N} \text { for a rise in } \\
\text { protein intake from } 0 \text { to } 100 \mathrm{mg} \mathrm{N} / 100 \mathrm{~g} \text { initial body-weight }\end{array}$} \\
\hline & $\begin{array}{l}\text { Expt II, } \\
\text { sample } 2\end{array}$ & $\begin{array}{l}\text { Expt 15, } \\
\text { sample } 4\end{array}$ & $\begin{array}{l}\text { Expt } 16, \\
\text { sample } 4\end{array}$ & $\begin{array}{l}\text { Expt 20, } \\
\text { sample } 5\end{array}$ \\
\hline 0 & $21 \cdot 8$ & 16.5 & $17 \cdot 2$ & $26^{\circ} 4$ \\
\hline I & - & - & 20.9 & -7 \\
\hline 2 & $32 \cdot 7^{*}$ & $26 \cdot 9^{*}$ & $28.9^{*}$ & $33 \cdot 2$ \\
\hline 4 & - & $22^{\prime} 4^{*}$ & - & - \\
\hline
\end{tabular}

Concentrations of soya proteins (g/100 g diet): Expts $I 1,15$ and $16-8$ and 16

Expt $20-6$ and 12

Significance of differences:

$$
\begin{gathered}
\text { Expt I I-soya }<\text { soya }+2 \mathrm{~g} \text { methionine }(P<0.0 \mathrm{I}) \\
\text { Expt I } 5 \text {-soya }<\text { soya }+2 \text { or } 4 \mathrm{~g} \text { methionine }(P<0.0 \mathrm{I}) \\
\text { Expt I6-soya }<\text { soya }+2 \mathrm{~g} \text { methionine }(P<0.00 \mathrm{I}) \\
\text { soya }+\mathrm{Ig} \text { methionine }<\text { soya }+2 \mathrm{~g} \text { methio- } \\
\text { nine }(P<0.00 \mathrm{I})
\end{gathered}
$$

* Regression lines were non-linear.

Table 5. Effect of methionine supplements on the nutritive value for rats of soya proteins, determined by the balance-sheet method at a protein concentration of $8 \mathrm{~g} / \mathrm{1} 00 \mathrm{~g}$ diet

(Each observation is the mean of twelve values obtained on individual rats)

$\begin{array}{cccc}\begin{array}{c}\text { DL-methionine } \\ \text { supplement } \\ \text { (g/16 g protein N) }\end{array} & \begin{array}{c}\text { Biological } \\ \text { value }\end{array} & \begin{array}{c}\text { True } \\ \text { digestibility }\end{array} & \begin{array}{c}\text { Net utilization } \\ \text { value }\end{array} \\ \text { Soya sample no. } 2 & \\ 3 & \begin{array}{c}72 \cdot 3 \\ 81 \cdot 7\end{array} & 84 \cdot 8 & 61 \cdot 4 \\ & \text { Soya sample no. } 4 & 70 \cdot 0 \\ \text { I } & 65 \cdot 0 & 92 \cdot 0 & \\ 2 & 80 \cdot 5 & 92 \cdot 8 & 59 \cdot 8 \\ 4 & 79 \cdot 5 & 91 \cdot 8 & 74 \cdot 7 \\ & 84 \cdot 9 & 92 \cdot 5 & 73 \cdot 0 \\ 0 & \text { Soya sample no. } 5 & 78 \cdot 5 \\ 2 & 76 \cdot 6 & 91 \cdot 9 & 70 \cdot 4 \\ & 88 \cdot 0 & 92 \cdot 6 & 81 \cdot 5\end{array}$

Significance of differences of biological values: Sample no. $2-$ soya $<$ soya $+3 \mathrm{~g}$ methionine

$$
(P<0.01)
$$

Sample no. 4 -soya $<$ soya $+\mathrm{I}, 2$ or $4 \mathrm{~g}$ methionine $(P<0.001)$

soya $+\mathrm{I}$ or $2 \mathrm{~g}$ methionine $<$ soya $+4 \mathrm{~g}$ methionine $(P<0.01)$

Sample no. $5-$ soya $<$ soya +2 g methionine $(P<0.001)$ 
liver- $\mathrm{N}$ or the balance-sheet method (Tables 4 and 5 ). With the liver- $\mathrm{N}$ method, the optimum effect was obtained with $2 \mathrm{~g}$ DL-methionine/ $6 \mathrm{~g}$ protein $\mathrm{N}$, whereas with the balance-sheet method addition of $4 \mathrm{~g}$ DL-methionine/ $\mathrm{l} 6 \mathrm{~g}$ protein $\mathrm{N}$ was more effective than that of $2 \mathrm{~g}$. In one liver- $\mathrm{N}$ assay, not shown in the table, methionine

Table 6. Nutritive value for rats of soya proteins supplemented with cyanocobalamin, choline and cystine, determined by the liver-nitrogen method

\begin{tabular}{|c|c|c|c|}
\hline & \multicolumn{3}{|c|}{$\begin{array}{l}\text { Increase }(\mathrm{mg} / \mathrm{r} 00 \mathrm{~g} \text { initial body-weight) in liver } \\
\text { for a rise in protein intake from o to } 100 \mathrm{mg} \mathrm{N} / \mathrm{I} 00 \\
\text { initial body-weight }\end{array}$} \\
\hline Supplement & $\begin{array}{l}\text { Expt I6, } \\
\text { sample } 4\end{array}$ & $\begin{array}{l}\text { Expt } 18, \\
\text { sample } 5\end{array}$ & $\begin{array}{l}\text { Expt 29, } \\
\text { sample } 5\end{array}$ \\
\hline None & $17 \cdot 2$ & $\mathbf{r} 7 \cdot \mathbf{I}$ & $17 \cdot 3$ \\
\hline Cyanocobalamin $(0.2 \mu \mathrm{g} /$ day $)$ & $18 \cdot 0$ & - & - \\
\hline Choline $(0.79 \mathrm{~g}$ instead of $0.19 \mathrm{~g} / \mathrm{kg}$ diet) & - & $16 \cdot 3$ & - \\
\hline L-cystine $(2 \cdot 1 \mathrm{~g} / \mathrm{I} 6 \mathrm{~g}$ protein $\mathrm{N})$ & - & - & $26 \cdot 2$ \\
\hline
\end{tabular}

Concentrations of soya proteins (g/100 g diet): Expts I6, I 8 and 29 (unsupplemented soya)- 8 and I 6 Expt 29 (soya + cystine) -7 and 14

Significance of differences:

Expt $29-$ soya $<$ soya + cystine $(P<0.01)$

Table 7. Effect of cystine, methionine and choline supplements on the nutritive value for rats of casein, determined by the liver-nitrogen method

Increase ( $\mathrm{mg} / \mathrm{r} 00 \mathrm{~g}$ initial body-weight) in liver $\mathrm{N}$ for a rise in protein intake from o to $100 \mathrm{mg} \mathrm{N} / 100 \mathrm{~g}$ initial body-weight

\begin{tabular}{|c|c|c|c|}
\hline Supplement & $\operatorname{Expt} 28$ & Expt 31 & Expt ${ }_{3} 8$ \\
\hline None & $26 \cdot 9$ & $26 \cdot 0$ & $30 \cdot 1$ \\
\hline L-cystine $(2 \cdot 1 \mathrm{~g} / 16 \mathrm{~g}$ casein $\mathrm{N})$ & $34 \cdot 6$ & - & $39 \cdot 2^{*}$ \\
\hline DL-methionine $(2.62 \mathrm{~g} / 16 \mathrm{~g}$ casein $\mathrm{N})$ & - & $37 \cdot 2$ & $39 \cdot 9^{*}$ \\
\hline Choline $(0.79 \mathrm{~g}$ instead of $0.19 \mathrm{~g} / \mathrm{kg}$ diet $)$ & - & 一 & $28 \cdot 3$ \\
\hline \multicolumn{4}{|c|}{$\begin{array}{l}\text { Concentrations of casein }(\mathrm{g} / \mathrm{r} 00 \mathrm{~g} \text { diet }): \text { No supplements-8 and } \mathrm{I} 6 \\
\text { With supplements: Expt } 28-7 \text { and } \mathrm{I} 4 \\
\text { Expt } 3 \mathrm{I}-5 \text { and } \mathrm{I0} \\
\text { Expt } 38-8 \text { and } \mathrm{I} 6\end{array}$} \\
\hline Significance of differences: & \multicolumn{3}{|c|}{$\begin{array}{l}\text { Expt } 28-\text { casein }<\text { casein }+ \text { cystine } \\
\quad(P<0.01) \\
\text { Expt } 31-\text { casein }<\text { casein }+ \text { methionine } \\
\quad(P<0.001) \\
\text { Expt } 38 \text { not calculated }\end{array}$} \\
\hline
\end{tabular}

had no effect. When the optimum amount of methionine was added to the soya proteins their nutritive value was raised to about that of casein or slightly higher, but never reached that of whole-egg proteins (Figs. 2 and 3 ).

The effect of a supplement of L-cystine was tested in one liver- $\mathrm{N}$ assay. The amount of sulphur added corresponded to that contained in a methionine supplement of $2.6 \mathrm{~g} / \mathrm{1} 6 \mathrm{~g}$ protein. The result was a definite improvement, similar to that with methionine (Table 6). Addition to the diet of cyanocobalamin or of extra choline was ineffective. 
Casein. When casein was supplemented with L-cystine or DL-methionine in such quantities that the sulphur content of the supplements was the same, the nutritive values and the net utilization values were raised to about the same extent (Tables 7 and 8). Addition of extra choline was ineffective.

Table 8. Effect of cystine, methionine and choline supplements on the nutritive value for rats of casein, determined by the balance-sheet method at a protein concentration of $8 \mathrm{~g} / \mathrm{I}$ 100 $\mathrm{g}$ diet

(Each observation is the mean of twelve values obtained on individual rats)

\begin{tabular}{|c|c|c|c|c|}
\hline Supplement & $\begin{array}{c}\text { No. of } \\
\text { observa- } \\
\text { tions }\end{array}$ & Biological value & True digestibility & $\begin{array}{c}\text { Net utilization } \\
\text { value }\end{array}$ \\
\hline & 3 & $80.8(79 \cdot 2-83.7)$ & $98 \cdot 8(97 \cdot 9-99 \cdot 3)$ & $79.8(77 \cdot 9-83.1)$ \\
\hline $\begin{array}{l}g / 16 \mathrm{~g} \text { casein } N) \\
\mathrm{e}(2 \cdot 62 \mathrm{~g} / \mathrm{I} 6 \mathrm{~g} \text { casein } N)\end{array}$ & $\begin{array}{l}3 \\
\mathbf{I}\end{array}$ & $\begin{array}{l}93 \cdot 1(9 I \cdot 0-96 \cdot 6) \\
97 \cdot 1\end{array}$ & $\begin{array}{l}99 \cdot 3(98 \cdot 5-100 \cdot 0) \\
99 \cdot 8\end{array}$ & $\begin{array}{l}92 \cdot 6(89 \cdot 9-96 \cdot 6) \\
96 \cdot 9\end{array}$ \\
\hline $\mathrm{g}$ instead of $0.19 \mathrm{~g} / \mathrm{kg}$ & 2 & $79 \cdot 6(76 \cdot 4 ; 82 \cdot 8)$ & $99^{\circ} \mathbf{I}(98 \cdot 7 ; 99.5)$ & $78.9\left(75^{\circ} 4 ; 82.4\right)$ \\
\hline
\end{tabular}

None

L-cystine $(2 \cdot 1 \mathrm{~g} / \mathrm{r} 6 \mathrm{~g}$ casein $\mathrm{N})$

DL-methionine $(2 \cdot 62 \mathrm{~g} / \mathrm{I} 6 \mathrm{~g}$ casein $\mathrm{N})$

Choline $(0.79 \mathrm{~g}$ instead of $0.19 \mathrm{~g} / \mathrm{kg}$ diet)

Significance of differences of biological values: casein $<$ casein + cystine in all experiments $(P<0.001)$; casein $<$ casein + methionine $(P<0.001)$.

Table 9. Effect of cortisone on the nutritive value for rats of casein and wheat gluten, determined by the liver-nitrogen method

\begin{tabular}{|c|c|c|c|c|}
\hline & & \multicolumn{3}{|c|}{ Mean liver $\mathrm{N}$ (mg/roo $\mathrm{g}$ initial body-weight) } \\
\hline Protein & $\begin{array}{l}\text { Cortisone } \\
\text { (mg/day) }\end{array}$ & $\begin{array}{l}\text { At a protein } \\
\text { intake of } \\
\text { roo } \mathrm{mg} \mathrm{N} / \mathrm{ro0} \mathrm{g} \\
\text { initial body-weight } \\
\qquad(a)\end{array}$ & $\begin{array}{l}\text { At zero } \mathrm{N} \text { intake } \\
(b)\end{array}$ & $\begin{array}{c}\text { Increase } \\
(a-b)\end{array}$ \\
\hline Casein & 0 & 123.7 & $93 \cdot 8$ & $29^{\circ} 9$ \\
\hline Casein & $2 \cdot 5$ & $150 \cdot 2$ & $120 \cdot 5$ & $29 \cdot 7$ \\
\hline Wheat gluten & 0 & I 10.0 & $93 \cdot 8$ & $16 \cdot 2$ \\
\hline Wheat gluten & $2 \cdot 5$ & $142 \cdot 6$ & 120.5 & $22 \cdot I$ \\
\hline
\end{tabular}

Concentrations of proteins ( $\mathrm{g} / \mathrm{r} 00 \mathrm{~g}$ diet): 8 and $\mathrm{r} 6$

Significance of differences: Liver $N$ at zero $N$ intake, no cortisone $<$ cortisone $(P<0.001)$

Increase in liver $\mathrm{N}$; with cortisone, wheat gluten $<$ casein $(P<0.01)$

without cortisone, wheat gluten $<$ casein $(P<0.001)$

Table I0. Effect of cortisone on the nutritive value for rats of casein and wheat gluten, determined by the balance-sheet method at a protein concentration of $8 \mathrm{~g} / \mathrm{I} \circ 0 \mathrm{~g}$ diet

(Each observation is the mean of eight values obtained on individual rats)

$\begin{array}{lcccc}\text { Protein } & \begin{array}{c}\text { Cortisone } \\ (\mathrm{mg} / \text { day) }\end{array} & \begin{array}{c}\text { Biological } \\ \text { value }\end{array} & \begin{array}{c}\text { True } \\ \text { digestibility }\end{array} & \begin{array}{c}\text { Net utilization } \\ \text { value }\end{array} \\ \text { Casein } & 0 & 90 \cdot 2 & 99 \cdot 6 & 89 \cdot 8 \\ \text { Casein } & 2 \cdot 5 & 56 \cdot 3 & 99 \cdot 7 & 56 \cdot \mathbf{1} \\ \text { Wheat gluten } & 0 & 57 \cdot \circ & 97 \cdot 1 & 55^{\circ} \cdot 4 \\ \text { Wheat gluten } & 2 \cdot 5 & 52 \cdot 4 & 99 \cdot 7 & 52 \cdot 2\end{array}$

Significance of differences of biological values: casein with cortisone or wheat gluten with or without cortisone $<$ casein without cortisone $(P<0.001)$. 


\section{Effect of cortisone}

The results (Table 9) show that cortisone raised the $\mathrm{N}$ content of the liver of animals in all groups, including that given the protein-free diet. It did not affect the nutritive value of casein but possibly improved that of wheat gluten. However, this effect did not reach statistical significance. With the balance-sheet method, cortisone lowered the net utilization value of casein but did not affect that of wheat gluten (Table ro).

\section{DISCUSSION}

The results confirm and extend the findings presented in the earlier paper (Henry et al. 1953). No further progress has been made in improving the precision of the liver- $\mathrm{N}$ method. In particular, the assays designed to obtain more definite information about the shape of the non-linear dose-response curves have been equivocal. In the technique of the seven- or eight-point assays only the first part of the dose-response curve is used. If this part of the curve deviates significantly from linearity, as often happens with egg or when casein or soya-bean proteins are supplemented with methionine, the estimate of the nutritive value varies according to the point on the dose-response curve at which the comparison is made. This inability to obtain such an estimate independent of protein intake might go a long way to explain the discrepancies between the values found by the liver- $\mathrm{N}$ and the balance-sheet methods.

This dilemma was recognized in the earlier paper when it was found that better agreement was obtained between the two methods if casein, instead of whole-egg proteins, was used as reference protein. Additional information obtained since then has not affected this conclusion (Figs. 2 and 3 ). In this connexion it is noteworthy that, when more complete dose-response curves were constructed from experiments in which diets with a wide range of protein levels were tested by the liver- $N$ method, the ratio of the nutritive values of casein and whole-egg proteins was identical with that obtained by the balance-sheet method.

The calculation of the nutritive values depends on the accuracy of the estimate of the point at which the regression lines intersect. It can be determined more accurately in a seven-point assay that includes a group of rats on a protein-free diet than in an eight-point assay that does not include such a group. It is recommended, therefore, that the seven-point assay be used in preference to the eight-point assay although only three instead of four proteins can then be compared.

In the earlier paper (Henry et al. 1953) attention was drawn to an apparent discrepancy between the nutritive value of soya proteins obtained by the liver- $\mathrm{N}$ method and their net utilization value. The comparison was then made with a high net utilization value recorded in the literature. Subsequent direct comparisons between the two methods for a number of samples of soya-bean meals and one sample of isolated soya proteins (Drackett) appear to have resolved this difficulty as they showed that marked differences occur in the nutritive value of different samples of soya-bean meal. When casein is taken as reference protein, samples 2 and 4 of soya give close agreement, for samples $\mathrm{I}$ and 5 the nutritive values obtained with the liver- $\mathrm{N}$ method are too low 
and for isolated soya proteins the nutritive value is too high (Fig. 3 ), the difference being about $15 \%$ in either direction.

The results of the experiments with cortisone administration confirm in principle the observations of Silber \& Porter (1953) and of Goodlad \& Munro (1959). Silber \& Porter (I953) showed that cortisone increased the protein content of the livers of rats fed on a protein-free or a $20 \%$ casein diet; cortisone also increased urinary $\mathrm{N}$ excretion in rats fed on a protein-free diet or on a diet containing egg albumin or an aminoacid mixture. Goodlad \& Munro (r959) confirmed and extended these findings, using rats fed on diets with different casein and energy levels. Silber \& Porter (1953) thought that cortisone did not affect the biological value of proteins determined by a $\mathrm{N}$-retention method, but our results seem to suggest that cortisone might have different effects on proteins of different biological values. This problem requires further study.

The results now reported confirm the view expressed earlier that the precision of the liver- $\mathrm{N}$ method does not reach that of the balance-sheet method. It may be added that, though the liver-N method lends itself less well to the determination of absolute nutritive values than the balance-sheet method, the fact that it requires less time than the latter makes it suitable for screening tests and for tests of comparison between two proteins, as for instance fresh and stored milk (Henry et al. 1953) and unsupplemented and supplemented soya proteins.

\section{SUMMARY}

I. The liver-N method with rats, described previously, has been used to determine the nutritive value of a number of proteins.

2. An attempt to determine the shape of the dose-response curves was only partly successful. Consequently it was not possible to improve the precision of the method.

3. It is recommended that seven-point assays with three protein sources be used in preference to eight-point assays with four and that casein be used as reference protein.

4. When casein was the standard of reference for a series of proteins there was good agreement between values obtained by the liver- $\mathrm{N}$ and balance-sheet methods for proteins with nutritive values equal to or less than that of casein.

5. The discrepancy, reported previously, between the two methods with soya proteins was found to be due to large differences between samples of soya-bean meal.

6. The nutritive values (liver- $\mathrm{N}$ method) and net utilization values (balance-sheet method) both of soya proteins and of casein were improved by supplements of methionine or of cystine. Cyanocobalamin or additional choline had no effect on the value of soya proteins and additional choline had no effect on that of casein.

7. At all levels of protein intake $\mathrm{N}$ deposition in liver was increased after cortisone injections. With the liver- $\mathrm{N}$ method the nutritive value of casein was not affected by cortisone but that of wheat gluten was possibly improved slightly. With the balancesheet method cortisone markedly decreased the net utilization value of casein but had no effect on that of wheat gluten. 


\section{REFERENCES}

Campbell, R. M. \& Kosterlitz, H. W. (1948). F. Physiol. 107, 383.

de Loureiro, A. (1931). Arch. Pat., Lisboa, 3, 72.

Goodlad, G. A. J. \& Munro, H. N. (1959). Biochem. F. 73, 343.

Henry, K. M. \& Kon, S. K. (1956). Brit. F. Nutr. 10, 39.

Henry, K. M., Kon, S. K., Lea, C. H. \& White, J. C. D. (1947-8). F. Dairy Res. 15, 229.

Henry, K. M., Kon, S. K. \& Watson, M. B. (1937). Milk and Nutrition, Part 1, p. 37. Reading: National Institute for Research in Dairying.

Henry, K. M., Kosterlitz, H. W. \& Quenouille, M. H. (1953). Brit. F. Nutr. 7, 5 I.

Mitchell, H. H. (1923-4). F. biol. Chem. 58, 873.

Mitchell, H. H. \& Carman, G. G. (1926). F. biol. Chem. 68, 183.

Silber, R. H. \& Porter, C. C. (1953). Endocrinology, 52, 5 I8. 